\title{
High-level soluble expression of the hem $A$ gene from Rhodobacter capsulatus and comparative study of its enzymatic properties*
}

\author{
Jia-wei LOU, Li ZHU, Mian-bin WU ${ }^{\dagger}$, Li-rong YANG, Jian-ping LIN ${ }^{\dagger}$, Pei-lin CEN \\ (Key Laboratory of Biomass Chemical Engineering of Ministry of Education, Department of Chemical and Biological Engineering, \\ Zhejiang University, Hangzhou 310027, China) \\ †E-mail: wumb@zju.edu.cn; linjp@zju.edu.cn
}

Received Nov. 8, 2013; Revision accepted Mar. 26, 2014; Crosschecked Apr. 9, 2014

\begin{abstract}
The Rhodobacter capsulatus hemA gene, which encodes 5-aminolevulinic acid synthase (ALAS), was expressed in Escherichia coli Rosetta (DE3) and the enzymatic properties of the purified recombinant ALAS (RC-ALAS) were studied. Compared with ALASs encoded by hemA genes from Agrobacterium radiobacter (AR-ALAS) and Rhodobacter sphaeroides (RS-ALAS), the specific activity of RC-ALAS reached $198.2 \mathrm{U} / \mathrm{mg}$, which was about $31.2 \%$ and $69.5 \%$ higher than those of AR-ALAS (151.1 U/mg) and RS-ALAS $(116.9 \mathrm{U} / \mathrm{mg})$, respectively. The optimum $\mathrm{pH}$ values and temperatures of the three above mentioned enzymes were all $\mathrm{pH} 7.5$ and $37^{\circ} \mathrm{C}$, respectively. Moreover, RC-ALAS was more sensitive to $\mathrm{pH}$, while the other two were sensitive to temperature. The effects of metals, ethylene diamine tetraacetic acid (EDTA), and sodium dodecyl sulfate (SDS) on the three ALASs were also investigated. The results indicate that they had the same effects on the activities of the three ALASs. SDS and metal ions such as $\mathrm{Co}^{2+}$, $\mathrm{Zn}^{2+}$, and $\mathrm{Cu}^{2+}$ strongly inhibited the activities of the ALASs, while $\mathrm{Mn}^{2+}$ exerted slight inhibition, and $\mathrm{K}^{+}, \mathrm{Ca}^{2+}, \mathrm{Ba}^{2+}$, $\mathrm{Mg}^{2+}$, or EDTA had no significant effect. The specificity constant of succinyl coenzyme A $\left[\left(k_{\text {cat }} / K_{m}\right)^{\mathrm{S}-\mathrm{CoA}}\right]$ of RC-ALAS was 1.4989, which was higher than those of AR-ALAS (0.7456) and RS-ALAS (1.1699), showing its high catalytic efficiency. The fed-batch fermentation was conducted using the recombinant strain containing the $R$. capsulatus hemA gene, and the yield of 5-aminolevulinic acid (ALA) achieved was $8.8 \mathrm{~g} / \mathrm{L}(67 \mathrm{mmol} / \mathrm{L})$ under the appropriate conditions.
\end{abstract}

Key words: 5-Aminolevulinic acid, Rhodobacter capsulatus, High-level expression, Enzymatic properties doi: 10.1631 jzus.B1300283

Document code: A

CLC number: Q819

\section{Introduction}

5-Aminolevulinic acid (ALA) is an endogenously synthesized amino acid involved in the synthesis of tetrapyrroles such as vitamin $\mathrm{B}_{12}$, heme, and chlorophyll in vivo. It is a precursor of tetrapyrroles and a key intermediate in regulating tetrapyrrole biosynthesis (Sasaki et al., 2002). ALA has been used in a number of applications, i.e., as a new kind of green pesticide in agriculture and as a photodynamic medi-

\footnotetext{
Corresponding authors

* Project supported by the National Natural Science Foundation of China (No. 20306026) and the National Basic Research Program (973) of China (No. 2007CB707805)

(C) Zhejiang University and Springer-Verlag Berlin Heidelberg 2014
}

cine for photodynamic diagnosis and therapy of cancer (Lang et al., 2001; Braathen et al., 2007; Berkovitch et al., 2008; Pariser et al., 2008; Zaak et al., 2008).

Compared with conventional methods, microbial production of ALA with new technologies such as genetic engineering and metabolic engineering has recently attracted much attention. Recombinant bacteria containing the hemA gene from such organisms as Rhodobacter sphaeroides (Vanderwerf and Zeikus, 1996; Kiatpapan and Murooka, 2001; Xie et al., 2003b; Wang et al., 2006; Fu et al., 2007), Bradyrhizobium japonicum (Choi et al., 1999; Lee et al., 2004), Rhodopseudomonas palustris (Choi et al., 2008), and Agrobacterium radiobacter (Liu et al., 
2005; Lin et al., 2009) were constructed for ALA production, achieving levels of $39 \mathrm{mmol} / \mathrm{L}$ (Xie et al., 2003a), $50 \mathrm{mmol} / \mathrm{L}$ (Fu et al., 2008), and $56 \mathrm{mmol} / \mathrm{L}$ (Lin et al., 2009), respectively.

In our previous work, ALA production by recombinant Escherichia coli containing the hemA gene from $R$. sphaeroides (Fu et al., 2007; 2008) and $A$. radiobacter zju-0121 (Lin et al., 2009; Fu et al., 2010) reached a relatively high level. However, it has been difficult to achieve a substantial breakthrough since our work mainly focused on the optimization of fermentation conditions. In this study, we investigated the difference in the hemA genes from different organisms as a starting point to obtain 5-aminolevulinic acid synthase (ALAS) with excellent enzymatic properties, which has high-level solubility expressed in recombinant $E$. coli, resulting in further enhancement of ALA production.

Rhodobacter capsulatus is a good source of the hemA gene. The gene was successfully cloned and expressed under the control of a constitutive promoter in $E$. coli, and the recombinant $E$. coli strain was able to accumulate ALA at $21 \mathrm{mmol} / \mathrm{L}$ (Kang et al., 2004). However, the enzymatic properties remain unknown. In this study, the $R$. capsulatus hemA gene was highly expressed in E. coli Rosetta (DE3), which is a rare codon optimizer host strain. The recombinant ALAS (RC-ALAS) was isolated and purified, and its enzymatic properties were investigated.

Since the methods and analytical instruments for the determination of enzyme activity vary in different reports, the enzymatic properties are likely to be different, even if the enzyme was encoded by the same hemA gene. For example, the activity of RS-ALAS, which was encoded by the hemA gene from $R$. sphaeroides, was reported to be $130 \mu \mathrm{mol} /(\mathrm{h} \cdot \mathrm{mg})$
(Warnick and Burnham, 1971), while it was found to be $13 \mu \mathrm{mol} /(\mathrm{h} \cdot \mathrm{mg})$ by Bolt et al. (1999). The activity of RP-ALAS, encoded by the hemA gene from Rhodopseudomonas palustris, has been reported as $65.23 \mathrm{nmol} /(\mathrm{h} \cdot \mathrm{mg}$ ) (Viale et al., 1987) and $27.73 \mu \mathrm{mol} /(30 \mathrm{~min} \cdot \mathrm{mg}$ ) (Choi et al., 2004), a difference of three orders of magnitude. To avoid this problem, the enzymatic properties of purified RC-ALAS were investigated under the same conditions for AR-ALAS and RS-ALAS, which were encoded by the hemA gene from $A$. radiobacter zju-0121 and $R$. sphaeroides, respectively.

\section{Materials and methods}

\subsection{Bacterial strains, plasmids, and growth conditions}

The bacterial strains and plasmids used in this study are listed in Table 1.

E. coli strains were cultivated in Luria-Bertani (LB) medium supplemented, when necessary, with kanamycin $(30 \mathrm{mg} / \mathrm{L})$ or chloramphenicol $(34 \mathrm{mg} / \mathrm{L})$. $R$. capsulatus was cultivated under anaerobic conditions in the light at $25{ }^{\circ} \mathrm{C}$, using modified Rhodospirillaceae medium containing $0.30 \mathrm{~g} / \mathrm{L}$ yeast extract, $1.00 \mathrm{~g} / \mathrm{L}$ sodium succinate, $0.50 \mathrm{~g} / \mathrm{L}$ ammonium acetate, $5.00 \mathrm{ml} \mathrm{Fe}(\mathrm{III})$ citrate solution $\left(1 \mathrm{~g} / \mathrm{L}\right.$ in $\left.\mathrm{H}_{2} \mathrm{O}\right)$, $0.50 \mathrm{~g} / \mathrm{L} \quad \mathrm{KH}_{2} \mathrm{PO}_{4}, 0.40 \mathrm{~g} / \mathrm{L} \quad \mathrm{MgSO}_{4} \cdot 7 \mathrm{H}_{2} \mathrm{O}, 0.40 \mathrm{~g} / \mathrm{L}$ $\mathrm{NaCl}, 0.40 \mathrm{~g} / \mathrm{L} \mathrm{NH} \mathrm{H}_{4} \mathrm{Cl}, 0.05 \mathrm{~g} / \mathrm{L} \mathrm{CaCl}{ }_{2} \cdot 2 \mathrm{H}_{2} \mathrm{O}, 0.40 \mathrm{ml}$ vitamin $\mathrm{B}_{12}$ solution $\left(10 \mathrm{mg}\right.$ in $\left.100 \mathrm{ml} \mathrm{H}_{2} \mathrm{O}\right), 1.00 \mathrm{ml}$ trace element solution SL-6 $\left(0.10 \mathrm{~g} / \mathrm{L} \mathrm{ZnSO}{ }_{4} \cdot 7 \mathrm{H}_{2} \mathrm{O}\right.$, $0.03 \mathrm{~g} / \mathrm{L} \mathrm{MnCl} \mathrm{Mn}_{2} \cdot 4 \mathrm{H}_{2} \mathrm{O}, 0.30 \mathrm{~g} / \mathrm{L} \mathrm{H}_{3} \mathrm{BO}_{3}, 0.20 \mathrm{~g} / \mathrm{L}$ $\mathrm{CoCl}_{2} \cdot 6 \mathrm{H}_{2} \mathrm{O}, \quad 0.01 \mathrm{~g} / \mathrm{L} \quad \mathrm{CuCl}_{2} \cdot 2 \mathrm{H}_{2} \mathrm{O}, \quad 0.02 \mathrm{~g} / \mathrm{L}$ $\mathrm{NiCl}_{2} \cdot 6 \mathrm{H}_{2} \mathrm{O}$, and $\left.0.03 \mathrm{~g} / \mathrm{L} \mathrm{Na}_{2} \mathrm{MoO}_{4} \cdot 2 \mathrm{H}_{2} \mathrm{O}\right), 0.3 \mathrm{~g} / \mathrm{L}$ L-cysteine chloride, and $0.50 \mathrm{ml}$ resazurin $(1 \mathrm{~g} / \mathrm{L}$ in $\mathrm{H}_{2} \mathrm{O}$ ).

Table 1 Bacterial strains and plasmids used in this study

\begin{tabular}{lcc}
\hline \multicolumn{1}{c}{ Strain or plasmid } & Relevant property & Source \\
\hline Strain & & DSMZ \\
Rhodobacter capsulatus ATCC 11166 & Type strain & Laboratory stock \\
E. coli Rosetta (DE3)/pET28a-A.R.hemA & $\mathrm{Cm}^{\mathrm{R}} \& \mathrm{Kan}^{\mathrm{R}}$ & Laboratory stock \\
E. coli Rosetta (DE3)/pET28a-R.S.hemA & $\mathrm{Cm}^{\mathrm{R}} \& \mathrm{Kan}^{\mathrm{R}}$ & Laboratory stock \\
E. coli Rosetta (DE3) & $\mathrm{Cm}^{\mathrm{R}}$ & Novagen \\
Plasmid & & $\mathrm{Kan}^{\mathrm{R}}$ \\
pET28a $(+)$ & & .
\end{tabular}

$\mathrm{Cm}^{\mathrm{R}}$ : chloramphenicol resistance; $\mathrm{Kan}^{\mathrm{R}}$ : kanamycin resistance; DSMZ: Deutsche Sammlung von Mikroorganismen und Zellkulturen GmbH 


\subsection{Construction of the expression plasmid con- taining the hem $A$ gene from $R$. capsulatus}

The genomic DNA of $R$. capsulatus was extracted by using a Bacterial Genomic DNA Miniprep Kit (Axygen). Two oligonucleotide primers, ALA1 (5'-GGGAATTCCATATGGACTACAATCTCGCG CTC-3') and ALA2 (5'-CCCAAGCTTAGGCCTCG GCGCGATTCAC-3'), which were designed with NdeI and HindIII restriction sites (underlined), respectively, were synthesized for the cloning of the hemA gene from the genomic DNA by polymerase chain reaction (PCR) amplification. The amplification was conducted in a 50- $\mu 1$ reaction mixture containing primers (10 pmol), genomic DNA (50 ng), $10 \mu \mathrm{l}$ of $5 \times$ PrimeSTAR GXL buffer, $4 \mu \mathrm{l}$ of dNTP mixture $(2.5 \mathrm{mmol} / \mathrm{L}$ each), and $1 \mu \mathrm{l}$ of PrimeSTAR GXL DNA polymerase (TaKaRa). The reaction mixture was amplified for 30 cycles of denaturation at $98^{\circ} \mathrm{C}$ for $10 \mathrm{~s}$, annealing at $58{ }^{\circ} \mathrm{C}$ for $15 \mathrm{~s}$, and extension at $72{ }^{\circ} \mathrm{C}$ for $80 \mathrm{~s}$.

The amplified 1.2-kb DNA fragment was isolated and cloned into the $\mathrm{pET} 28 \mathrm{a}(+)$ expression vector (Fig. 1). The resulting plasmid, designated pET28aR.C.hemA, was transformed into E. coli Rosetta (DE3) to obtain E. coli Rosetta (DE3)/pET28a-R.C.hemA.

\subsection{Expression of recombinant hemA gene and purification of ALAS}

The three recombinant ALASs, RC-ALAS, AR-ALAS, and RS-ALAS, were expressed and purified using the method described in our previous work (Lin et al., 2009). Specifically, for the cultivation of recombinant $E$. coli, LB medium supplemented with kanamycin (30 mg/L) and chloramphenicol (34 mg/L) was used. After incubation for $2 \mathrm{~h}$ at $37^{\circ} \mathrm{C}$, isopropyl$\beta$-D-thiogalactopyranoside (IPTG) was added to induce the expression of ALAS at the final concentration of $0.05 \mathrm{mmol} / \mathrm{L}$, and the mixture was incubated for $6 \mathrm{~h}$ at $28{ }^{\circ} \mathrm{C}$. Cells were harvested by centrifugation $\left(10000 \times g\right.$ for $10 \mathrm{~min}$ at $\left.4{ }^{\circ} \mathrm{C}\right)$. The cells were resuspended in $50 \mathrm{mmol} / \mathrm{L}$ Tris-buffer $(\mathrm{pH} 7.5)$, and then disrupted with an ultrasonicator (Ningbo Scientz Biotechnology, China) for $6 \mathrm{~min}$. After re-centrifugation $\left(10000 \times g\right.$ for $10 \mathrm{~min}$ at $\left.4{ }^{\circ} \mathrm{C}\right)$, the 6-His-tagged ALAS in the supernatant was recovered by affinity purification on nickel-nitrilotriacetic acid (Ni-NTA) according to the manufacturer's instructions (Qiagen, Germany), and was eluted with imidazole and $\mathrm{NaCl}$. Sephadex

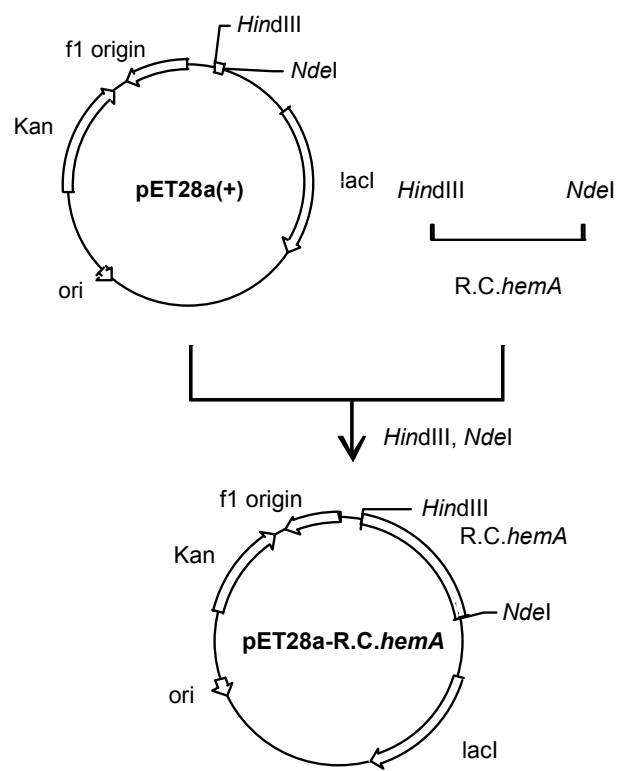

Fig. 1 Construction of expression vector

G-25 medium resin (GE Healthcare, USA) was used for gel filtration chromatography to remove imidazole and $\mathrm{NaCl}$ from the ALAS solution to obtain purified ALAS. The purity of ALAS was determined by sodium dodecyl sulfate polyacrylamide gel electrophoresis (SDS-PAGE) analysis.

\subsection{Assay for enzyme activity and ALA}

Protein concentrations were measured using a Pierce BCA protein assay kit (Sigma, St. Louis, MO, USA) with bovine serum albumin as the standard. The enzyme assay was carried out according to our previous work (Lin et al., 2009) with slight modification. The assays were conducted in a $500-\mu 1$ reaction mixture containing $380 \mu \mathrm{l}$ of about $0.1 \mathrm{mg} / \mathrm{ml}$ purified ALAS and $120 \mu \mathrm{l}$ of reaction liquid containing $50 \mu \mathrm{l}$ of $1 \mathrm{~mol} / \mathrm{L}$ glycine, $50 \mu \mathrm{l}$ of $2 \mathrm{mmol} / \mathrm{L}$ succinyl-CoA, $6 \mu 1$ of $1 \mathrm{~mol} / \mathrm{L}$ Tris-buffer (pH 7.5), and $14 \mu \mathrm{l}$ of $10 \mathrm{mmol} / \mathrm{L}$ pyridoxal phosphate, which were mixed together after preheating at $37{ }^{\circ} \mathrm{C}$ for $5 \mathrm{~min}$, respectively. After proceeding at $37{ }^{\circ} \mathrm{C}$ for $10 \mathrm{~min}$, the reaction was terminated by the addition of $150 \mu \mathrm{l}$ of $10 \%(\mathrm{v} / \mathrm{v})$ trichloroacetic acid. Then, the sample was centrifuged and assayed to determinate the concentration of ALA in the supernatant. One unit of ALAS activity was defined as the amount of enzyme needed to produce $1 \mathrm{nmol}$ of ALA in $1 \mathrm{~min}$. The ALA concentration was determined according to our previous work (Fu et al., 2008). Specifically, $2 \mathrm{ml}$ of sample or standard was mixed with $1 \mathrm{ml} 1.0 \mathrm{~mol} / \mathrm{L}$ 
sodium acetate ( $\mathrm{pH} 4.6)$ in a cuvette. Then the mixtures were heated at $100{ }^{\circ} \mathrm{C}$ for $15 \mathrm{~min}$. After cooling for $15 \mathrm{~min}, 2 \mathrm{ml}$ of reaction mixture and $2 \mathrm{ml}$ freshly prepared modified Ehrlich's reagent (Burnham, 1970) were mixed together. After $30 \mathrm{~min}$, the absorbance at $554 \mathrm{~nm}$ was measured.

\subsection{Enzyme properties of ALAS}

The enzymatic properties of purified RC-ALAS, AR-ALAS, and RS-ALAS were studied under the same conditions. The enzymatic reactions were assayed at various $\mathrm{pH}$ values and temperatures to determine the optimum $\mathrm{pH}$ and temperature, as well as $\mathrm{pH}$ and temperature stability. The effects of various metal ions, SDS, and ethylene diamine tetraacetic acid (EDTA) on enzyme activity were also evaluated. All the measurements were performed with $0.1 \mathrm{mg} / \mathrm{ml}$ ALAS in $50 \mathrm{mmol} / \mathrm{L}$ Tris- $\mathrm{HCl}(\mathrm{pH}$ 7.5) buffer. The glycine concentration was set at $100 \mathrm{mmol} / \mathrm{L}$ and different concentrations of succinyl-CoA were used to examine the relationship between the initial velocity and the substrate concentration. The kinetic parameters, Michaelis constant $\left(K_{\mathrm{m}}\right)$ and maximal velocity $\left(V_{\max }\right)$, were determined by fitting the data to the Michaelis-Menten equation using non-linear regression analysis software (SigmaPlot10; Systat).

\subsection{Fermentation conditions}

Seed cultures were incubated for $3 \mathrm{~h}$ at $200 \mathrm{r} / \mathrm{min}$ and at $37{ }^{\circ} \mathrm{C}$ in shaken flasks containing $200 \mathrm{ml} \mathrm{LB}$ medium supplemented with kanamycin $(30 \mathrm{mg} / \mathrm{L})$ and chloramphenicol $(34 \mathrm{mg} / \mathrm{L})$. The fermentation was conducted in a 15-L fermenter (Shanghai Guoqiang Bioengineering Equipment Co., Ltd., China). Nine-liter sterilized fermentation medium containing $20 \mathrm{~g} / \mathrm{L}$ glycerol, $10 \mathrm{~g} / \mathrm{L}$ yeast extract, $2 \mathrm{~g} / \mathrm{L}$ glycine, and $3 \mathrm{~g} / \mathrm{L}$ succinic acid was added, and $400 \mathrm{ml}$ seed culture was inoculated to provide an initial optical density at $600 \mathrm{~nm}\left(\mathrm{OD}_{600}\right)$ of approximately 0.1 . The fermenter was operated at $400 \mathrm{r} / \mathrm{min}$ and the air flow rate was regulated at $6 \mathrm{~L} / \mathrm{min}$. After cultivation at $37^{\circ} \mathrm{C}$ for $2 \mathrm{~h}$, IPTG was added and the temperature was lowered to $28{ }^{\circ} \mathrm{C}$. During the fermentation, the feed addition was performed by a peristaltic pump. The feed stream was a mixture of precursors containing $75 \mathrm{~g} / \mathrm{L}$ succinic acid and $65 \mathrm{~g} / \mathrm{L}$ glycine, and the feeding rate was regulated by the $\mathrm{pH}$ feed-back control system to maintain the $\mathrm{pH}$ value.

\section{Results and discussion}

\subsection{Cloning and expression of the $R$. capsulatus hem $A$ gene}

As shown in Fig. 2, a 1.2-kb DNA fragment carrying hemA gene was isolated by PCR from genomic DNA of $R$. capsulatus. Sequencing experiments showed that the hemA coding region was $1206 \mathrm{bp}$ long, indicating a protein of 402 amino acids with a molecular weight of about $44 \mathrm{kD}$. The DNA sequence showed $77 \%$ homology with the A. radiobacter zju-0121 hemA gene (GeneID: 88174324) and $64 \%$ homology with the $R$. sphaeroides hemA gene (GeneID: 3720398). Meanwhile, the amino acid sequence of RC-ALAS shared $58 \%$ identity with AR-ALAS and $75 \%$ identity with RS-ALAS, which suggested that the enzymatic properties of the three ALASs might be different.

The SDS-PAGE analysis of the recombinant RC-ALAS, which was highly expressed by E. coli Rosetta (DE3)/pET28a-R.C.hemA, is shown in Fig. 3.

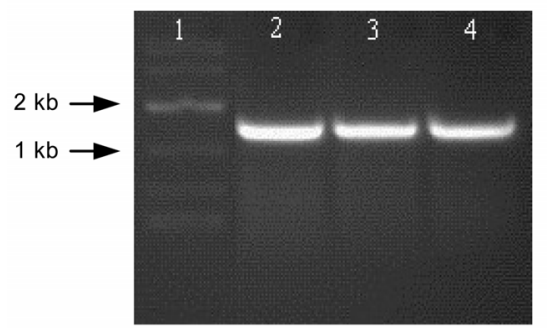

Fig. 2 Agarose gel electrophoresis analysis of hemA from $R$. capsulatus

Lane 1: marker; Lanes 2-4: hemA

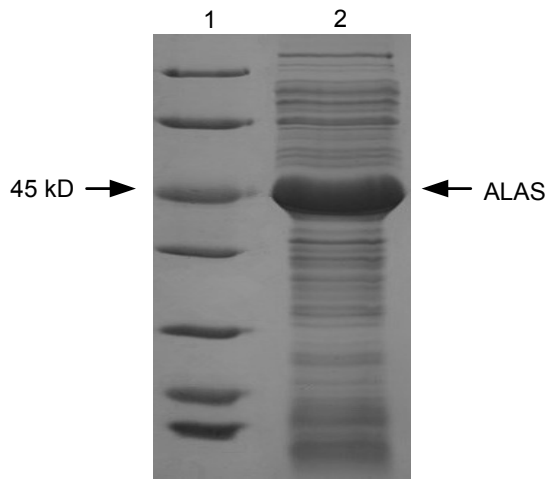

Fig. 3 Expression of the $R$. capsulatus hem $A$ gene in E. coli Rosetta (DE3)

Lane 1: marker; Lane 2: crude RC-ALAS

\subsection{Enzymatic properties of recombinant ALAS}

The purified recombinant proteins, RC-ALAS, 
AR-ALAS, and RS-ALAS, were obtained after Ni-NTA agarose affinity purification and Sephadex G-25 medium resin gel filtration chromatography, and the purity was determined by SDS-PAGE with about $0.1 \mathrm{mg} / \mathrm{ml}$ ALAS, as shown in Fig. 4 . The enzymatic properties of all three were studied under the same conditions.

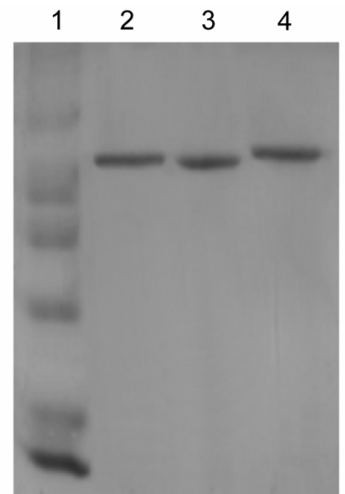

Fig. 4 SDS-PAGE analysis of purified recombinant ALASs

Lane 1: marker; Lane 2: RC-ALAS; Lane 3: AR-ALAS; Lane 4: RS-ALAS

\subsubsection{Optimum temperature}

The enzymatic reactions were assayed at various temperatures ranging from 22 to $42{ }^{\circ} \mathrm{C}$. As shown in Fig. 5, the optimum temperature of all three enzymes was found to be $37^{\circ} \mathrm{C}$. Among the three, a marked effect of temperature was observed for AR-ALAS, while a minimal impact was found for RC-ALAS. In particular, when the temperature was lowered from 37 to $22{ }^{\circ} \mathrm{C}$, the specific activities of the three enzymes dropped to below $50 \%$. Moreover, when the temperature was increased to $42{ }^{\circ} \mathrm{C}$, a significant decrease in enzyme activity was observed. It was concluded that the fermentation temperature could directly influence the enzyme activity. This result suggests that we need to consider the effects of temperature on the growth of recombinant bacteria, as well as the expression and specific activity of the recombinant enzyme as a whole during fermentation.

\subsubsection{Optimum $\mathrm{pH}$}

The enzymatic reactions were assayed at various $\mathrm{pH}$ values ranging from 6.5 to 8.5. As shown in Fig. 6, the optimum $\mathrm{pH}$ value of all three enzymes was 7.5. Acid effectively inhibited the activity of RC-ALAS, since its activity dropped to below $80 \%$, while the other two remained above $90 \%$ at $\mathrm{pH}$ 6.5. Conversely, strong alkaline conditions exerted the greatest inhibition of the activity of AR-ALAS, and had a minimal impact on RS-ALAS.

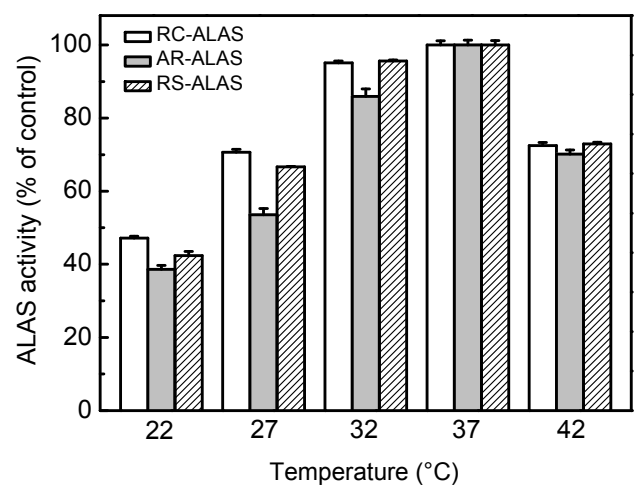

Fig. 5 Effects of various temperatures on the activity of recombinant ALAS

The activity of the sample assayed at $37{ }^{\circ} \mathrm{C}$ was set as $100 \%$. Data are expressed as mean \pm SD $(n=9)$

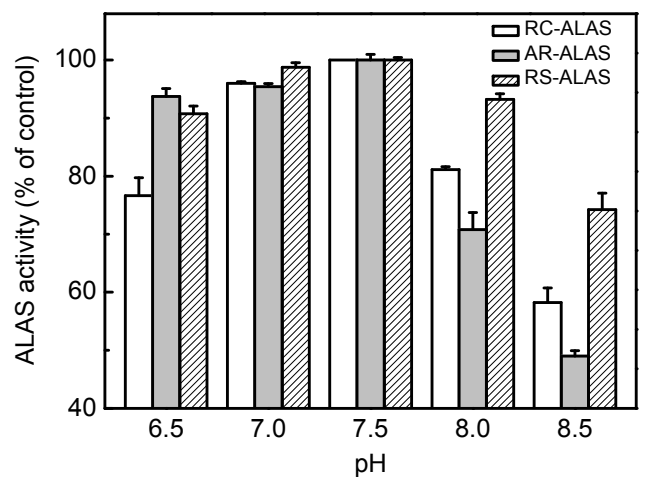

Fig. 6 Effects of various $\mathrm{pH}$ values on the activity of recombinant ALAS

The activity of the sample assayed at $\mathrm{pH} 7.5$ was set as $100 \%$. Data are expressed as mean $\pm \operatorname{SD}(n=9)$

According to previous work (Fan, 2006), ALA was found to be unstable in aqueous solution, which was dependent on various parameters such as $\mathrm{pH}$ and temperature. ALA degraded with increased $\mathrm{pH}$, and it was relatively stable in acidic conditions. Generally, ALA production was carried out in slightly acidic conditions, owing to its instability in alkaline conditions and difficulties in applications with strongly acidic conditions. As shown in Fig. 6, a nearly 20\% decline in the activity of RC-ALAS was observed when the $\mathrm{pH}$ decreased from 7.0 to 6.5 , indicating that a slight increase of the initial medium $\mathrm{pH}$ value may result in greater ALA production. This result suggests that the 

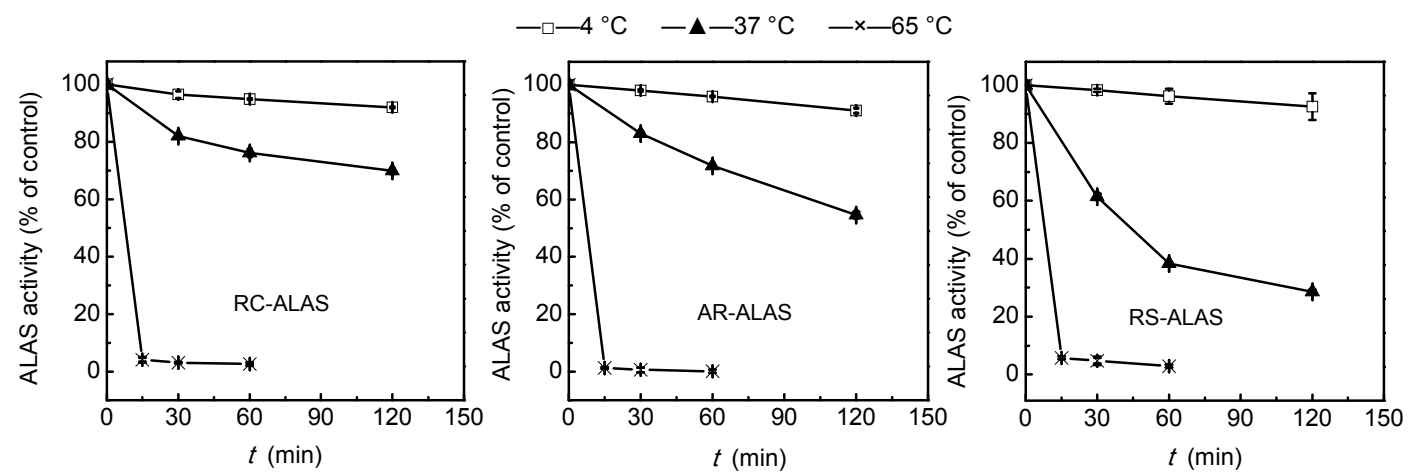

Fig. 7 Temperature stability of recombinant ALAS

Data are expressed as mean $\pm \mathrm{SD}(n=3)$

control of $\mathrm{pH}$ during fermentation is particularly important for the recombinant strain E. coli Rosetta (DE3)/pET28a-R.C.hemA .

\subsubsection{Enzyme activity}

The specific activity was assayed at the optimum temperature of $37{ }^{\circ} \mathrm{C}$ and optimum $\mathrm{pH}$ of 7.5. As listed in Table 2, the activity of RC-ALAS reached $198.2 \mathrm{U} / \mathrm{mg}$, which was about $31.2 \%$ and $69.5 \%$ higher than those of AR-ALAS and RS-ALAS, respectively. Currently, the recombinant strain E. coli Rosetta (DE3)/pET28a-A.R.hemA is used in industrial mass production. Furthermore, the recombinant strain E. coli Rosetta (DE3)/pET28a-R.C.hemA may achieve much greater ALA production via the optimization of fermentation conditions, indicating its potential prospects for industrial application.

Table 2 Activity of recombinant ALAS

\begin{tabular}{ccc}
\hline \multirow{2}{*}{ ALAS } & \multicolumn{2}{c}{ Activity (U/mg) } \\
\cline { 2 - 3 } & Crude enzyme & Purified enzyme \\
\hline RC-ALAS & 47.0 & 198.2 \\
AR-ALAS & 19.5 & 151.1 \\
RS-ALAS & 33.6 & 116.9 \\
\hline
\end{tabular}

\subsubsection{Temperature and $\mathrm{pH}$ stability}

The temperature and $\mathrm{pH}$ stabilities of the three enzymes are shown in Figs. 7 and 8, respectively. After storage for $60 \mathrm{~min}$ at $65^{\circ} \mathrm{C}$, the three enzymes lost all their activity. After storage for $120 \mathrm{~min}$ at $37{ }^{\circ} \mathrm{C}$, RS-ALAS retained only about $30 \%$ of its activity, while AR-ALAS retained about $50 \%$. However, about $90 \%$ of activity remained after storage for $120 \mathrm{~min}$ at $4{ }^{\circ} \mathrm{C}$. It is clear, therefore, that ALAS should be

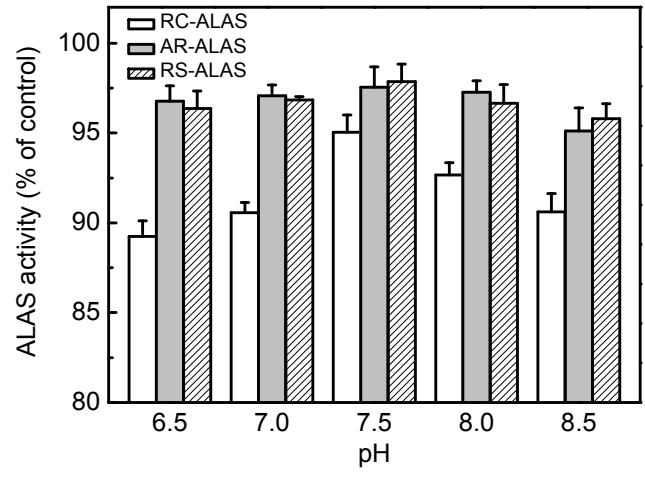

Fig. 8 pH stability of recombinant ALAS Data are expressed as mean $\pm \mathrm{SD}(n=3)$

stored at a low temperature. All three enzymes were stable in the $\mathrm{pH}$ range 6.5 to 8.5 with all activities retained about or above $90 \%$. In particular, RC-ALAS was more sensitive to $\mathrm{pH}$, while the other two were sensitive to temperature.

\subsubsection{Effects of metal ions, EDTA, and SDS}

In many cases, metal ions are bound to enzymes and play central roles in the catalytic process. Metal ions can function catalytically by forming nucleophiles, by direct coordination, by serving as electrophiles to stabilize a negative charge on a reactive intermediate, and by serving as a bridge between the enzyme and the substrate, which increases the binding energy. However, some heavy metals may cause enzyme denaturation.

The effects of various metal ions on enzyme activity were examined when the concentration of metal ions was set at $2 \mathrm{mmol} / \mathrm{L}$. As shown in Fig. 9, the effects on the activities of the three enzymes were almost the same. Metal ions such as $\mathrm{Co}^{2+}, \mathrm{Zn}^{2+}$, and $\mathrm{Cu}^{2+}$ strongly inhibited the activity of ALAS, while 
$\mathrm{K}^{+}, \mathrm{Ca}^{2+}, \mathrm{Ba}^{2+}$, or $\mathrm{Mg}^{2+}$ had no significant effect. $\mathrm{Mn}^{2+}$ slightly inhibited the activity of ALAS, contrary to the observation in our previous work (Lin et al., 2009). This difference is probably attributable to the fact that, in our previous work, we used a higher concentration of metal ions, thus exceeding the buffering capacity of the $50 \mathrm{mmol} / \mathrm{L}$ Tris- $\mathrm{HCl}$ buffer used.

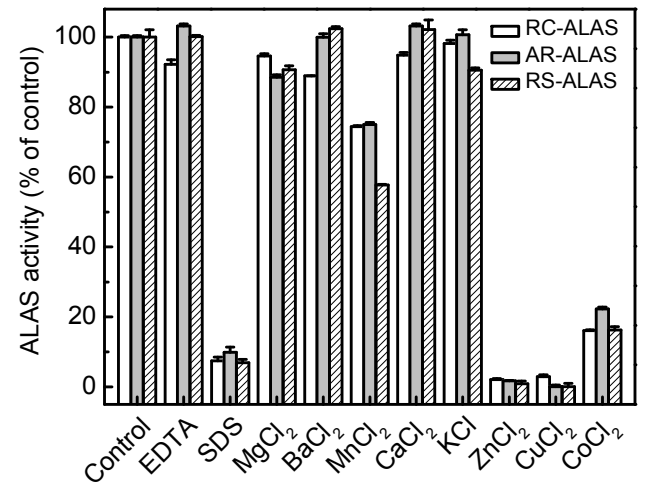

Fig. 9 Effects of various metal ions, EDTA, and SDS on the activity of recombinant ALAS

The activity of the untreated sample was set as $100 \%$. Data are expressed as mean $\pm \mathrm{SD}(n=3)$

As a metal ion chelator, EDTA can eliminate the interference caused by most of the metal ions, without affecting the function of the protein. We investigated whether EDTA influenced the activities of the three recombinant enzymes. The results show that EDTA had no significant effect on the activity of ALAS, indicating that metal ions are not required in the catalysis process.

SDS is an anionic detergent that can impart a negative charge or cause conformational changes to the active site of an enzyme, thus affecting its stability and activity. The results show that SDS significantly inhibited the activity of ALAS by as much as $90 \%$.

\subsubsection{Michaelis constant}

The Michaelis constant, $K_{\mathrm{m}}$, is an important kinetic parameter of an enzyme. It is an inverse measure of the substrate's affinity for the enzyme, so a small $K_{\mathrm{m}}$ value indicates a high affinity. The turnover number, $k_{\text {cat }}$, is the maximum number of substrate molecules converted to product per enzyme molecule per second. The ratio of $k_{\text {cat }} / K_{\mathrm{m}}$ is often used as a measure of enzyme efficiency.

ALAS catalyzes the condensation of glycine and succinyl-CoA to produce ALA, in which the sub- strates are glycine and succinyl-CoA. However, in the actual production, succinyl-CoA is replaced by succinic acid, which is often used as a precursor that can transform reversibly to succinyl-CoA via the Krebs cycle; there are many inherent difficulties in the mass production and storage of succinyl-CoA. Meanwhile, glycine is often added in excess to enhance ALA production because of its low price, thus making succinyl-CoA the limiting factor of the reaction rate. Therefore, a higher affinity between ALAS and succinyl-CoA means better production of ALA.

The relationship between the initial velocity and the concentration of succinyl-CoA, ranging from 0.05 to $0.40 \mathrm{mmol} / \mathrm{L}$, was examined while the concentration of glycine was set at $100 \mathrm{mmol} / \mathrm{L}$. The kinetic parameters, $K_{\mathrm{m}}$ and $V_{\max }$, were determined by fitting the data to the Michaelis-Menten equation using nonlinear regression analysis software (SigmaPlot10). The turnover number $k_{\mathrm{cat}}$ and the specificity constant of succinyl coenzyme A $\left[\left(k_{\mathrm{cat}} / K_{\mathrm{m}}\right)^{\mathrm{S}-\mathrm{CoA}}\right]$ were calculated and shown in Table 3 . The $\left(k_{\mathrm{cat}} / K_{\mathrm{m}}\right)^{\mathrm{S}-\mathrm{CoA}}$ of RC-ALAS was 1.4989 , which was higher than those of AR-ALAS and RS-ALAS, indicating its higher catalytic efficiency.

Table 3 Kinetic parameters of the enzymatic reaction of recombinant ALAS

\begin{tabular}{cccc}
\hline ALAS & $\begin{array}{c}K_{\mathrm{m}}^{\mathrm{S}-\mathrm{CoA}} \\
(\mathrm{mmol} / \mathrm{L})\end{array}$ & $\begin{array}{c}k_{\mathrm{cat}} \\
\left(\mathrm{s}^{-1}\right)\end{array}$ & $\begin{array}{c}\left(k_{\mathrm{cat}} / K_{\mathrm{m}}\right)^{\mathrm{S}-\mathrm{CoA}} \\
(\mathrm{L} /(\mathrm{mmol} \cdot \mathrm{s}))\end{array}$ \\
\hline RC-ALAS & 0.1986 & 0.2977 & 1.4989 \\
AR-ALAS & 0.2674 & 0.1994 & 0.7456 \\
RS-ALAS & 0.0764 & 0.0894 & 1.1699 \\
\hline
\end{tabular}

\subsection{ALA production by E. coli Rosetta (DE3)/ pET28a-R.C.hemA}

Based on the above results, E. coli Rosetta (DE3)/ pET28a-R.C.hemA may be a high-yield strain for ALA production. It was therefore desirable to carry out the fermentation using E. coli Rosetta (DE3)/ pET28a-R.C.hemA. In this work, a 15-L fermenter was used, and fed-batch fermentation carried out under the conditions that the above results suggest. The $\mathrm{pH}$ value was controlled at 6.2 initially and at 6.5 after $6 \mathrm{~h}$ of incubation with the $\mathrm{pH}$ feed-back controlled precursor feeding method. Meanwhile, the temperature was lowered to $28^{\circ} \mathrm{C}$ after $2 \mathrm{~h}$ of incubation for the better expression of the $R$. capsulatus hem $A$ gene, and increased to $37^{\circ} \mathrm{C}$ after $22 \mathrm{~h}$ to 
enhance the catalytic ability of RC-ALAS and the growth of the recombinant strain.

The results in Fig. 10 show that the yield of ALA achieved was $8.8 \mathrm{~g} / \mathrm{L}(67 \mathrm{mmol} / \mathrm{L})$ using the recombinant strain E. coli Rosetta (DE3)/pET28a-R.C.hemA under the appropriate conditions in the fermenter. This suggests that using the hemA gene from $R$. capsulatus increased the ALA yield over $20 \%$ and $33 \%$, respectively, than the yields achieved by recombinant $E$. coli containing the hemA gene from $A$. radiobacter zju-0121 (Lin et al., 2009; Fu et al., 2010) and $R$. sphaeroides (Fu et al., 2007; 2008).

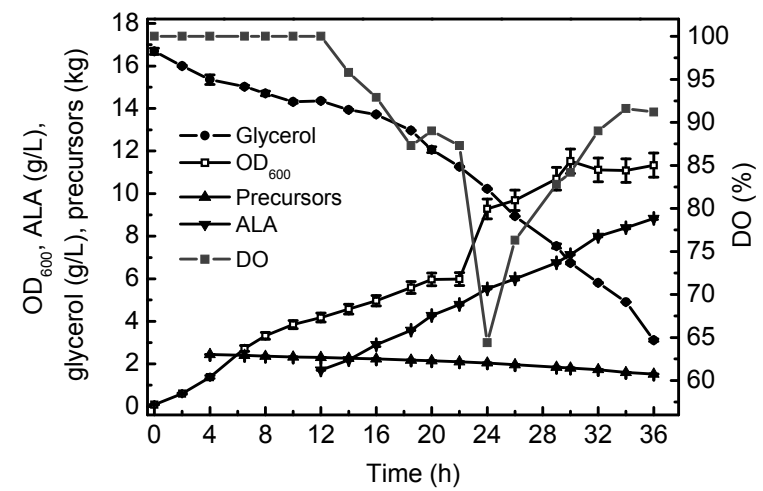

Fig. 10 Production of ALA using E. coli Rosetta (DE3)/ pET28a-R.C.hemA

Mixture of glycine and succinate acid was added continuously by the $\mathrm{pH}$ feed-back control system. The $\mathrm{pH}$ value was controlled at 6.2 initially and at 6.5 after $6 \mathrm{~h}$ of incubation. The temperature was controlled at $28^{\circ} \mathrm{C}$ after $2 \mathrm{~h}$ of incubation and increased to $37{ }^{\circ} \mathrm{C}$ after $22 \mathrm{~h}$. Data are expressed as mean $\pm \mathrm{SD}(n=3)$

\section{Conclusions}

The hemA gene from R. capsulatus (DSM1710) was highly expressed in E. coli Rosetta (DE3), and its enzymatic properties were investigated in comparison with AR-ALAS and RS-ALAS. The activity of purified RC-ALAS reached $198.2 \mathrm{U} / \mathrm{mg}$, which was about $31.2 \%$ and $69.5 \%$ higher than those of AR-ALAS (151.1 U/mg) and RS-ALAS (116.9 U/mg), respectively.

The results of the enzymatic properties suggest that we need to consider the effects of all the factors mentioned above on the growth of recombinant bacteria, as well as the expression and specific activity of the recombinant enzyme as a whole during fermentation to enhance the production of ALA. The fed-batch fermentation was conducted using recombinant strain E. coli Rosetta (DE3)/pET28a-R.C.hemA, and the yield of ALA achieved was $8.8 \mathrm{~g} / \mathrm{L}(67 \mathrm{mmol} / \mathrm{L})$, indicating a good potential for its industrial applications.

\section{Compliance with ethics guidelines}

Jia-wei LOU, Li ZHU, Mian-bin WU, Li-rong YANG, Jian-ping LIN, and Pei-lin CEN declare that they have no conflict of interest.

This article does not contain any studies with human or animal subjects performed by any of the authors.

\section{References}

Berkovitch, G., Doron, D., Nudelman, A., et al., 2008. Novel multifunctional acyloxyalkyl ester prodrugs of 5-aminolevulinic acid display improved anticancer activity independent and dependent on photoactivation. J. Med. Chem., 51(23):7356-7369. [doi:10.1021/jm8008794]

Bolt, E.L., Kryszak, L., Zeilstra-Ryalls, J., et al., 1999. Characterization of the Rhodobacter sphaeroides 5-aminolaevulinic acid synthase isoenzymes, HemA and HemT, isolated from recombinant Escherichia coli. Eur. J. Biochem., 265(1):290-299. [doi:10.1046/j.1432-1327. 1999.00730.x]

Braathen, L.R., Szeimies, R.M., Basset-Seguin, N., et al., 2007. Guidelines on the use of photodynamic therapy for nonmelanoma skin cancer: an international consensus. International Society for Photodynamic Therapy in Dermatology, 2005. J. Am. Acad. Dermatol., 56(1):125-143. [doi:10.1016/j.jaad.2006.06.006]

Burnham, B.F., 1970. $\delta$-Aminolevulinic acid synthase (from Rhodopseudomonas sphaeroides). In: Methods in Enzymology, Volume 17, Metabolism of Amino Acids and Amines, Part A. Academic Press, USA, p.195-200. [doi:10.1016/0076-6879(71)17179-0]

Choi, C., Hong, B.S., Sung, H.C., et al., 1999. Optimization of extracellular 5-aminolevulinic acid production from Escherichia coli transformed with ALA synthase gene of Bradyrhizobium japonicum. Biotechnol. Lett., 21(6): 551-554. [doi:10.1023/A:1005520007230]

Choi, H.P., Hong, J.W., Rhee, K.H., et al., 2004. Cloning, expression, and characterization of 5-aminolevulinic acid synthase from Rhodopseudomonas palustris KUGB306. FEMS Microbiol. Lett., 236(2):175-181. [doi:10.1111/j. 1574-6968.2004.tb09644.x]

Choi, H.P., Lee, Y.M., Yun, C.W., et al., 2008. Extracellular 5-aminolevulinic acid production by Escherichia coli containing the Rhodopseudomonas palustris KUGB306 hemA gene. J. Microbiol. Biotechnol., 18(6):1136-1140.

Fan, L., 2006. Study on Analysis and Stability of 5-Aminolevulinic Acid. MS Thesis, Zhejiang University, Hangzhou, China.

Fu, W.Q., Lin, J.P., Cen, P.L., 2007. 5-Aminolevulinate production with recombinant Escherichia coli using a rare codon optimizer host strain. Appl. Microbiol. Biotechnol., 75(4):777-782. [doi:10.1007/s00253-007-0887-y]

Fu, W.Q., Lin, H.P., Cen, P.L., 2008. Enhancement of 5-aminolevulinate production with recombinant Escherichia coli using batch and fed-batch culture system. Bioresource Technol., 99(11):4864-4870. [doi:10.1016/j. biortech.2007.09.039]

Fu, W.Q., Lin, J.P., Cen, P.L., 2010. Expression of a hemA gene from Agrobacterium radiobacter in a rare codon optimizing 
Escherichia coli for improving 5-aminolevulinate production. Appl. Microbiol. Biotechnol., 160(2):456-466.

Kang, D.K., Kim, S.S., Chi, W.J., et al., 2004. Cloning and expression of the Rhodobacter capsulatus hemA gene in $E$. coli for the production of 5-aminolevulinic acid. $J$. Microbiol. Biotechnol., 14(6):1327-1332.

Kiatpapan, P., Murooka, Y., 2001. Construction of an expression vector for propionibacteria and its use in production of 5-aminolevulinic acid by Propionibacterium freudenreichii. Appl. Microbiol. Biotechnol., 56(1-2):144-149. [doi:10.1007/s002530100603]

Lang, K., Lehmann, P., Bolsen, K., et al., 2001. Aminolevulinic acid: pharmacological profile and clinical indication. Expert Opin. Investig. Drugs, 10(6):1139-1156. [doi:10.1517/13543784.10.6.1139]

Lee, D.H., Jun, W.J., Yoon, J.W., et al., 2004. Process strategies to enhance the production of 5-aminolevulinic acid with recombinant E. coli. J. Microbiol. Biotechnol., 14(6): 1310-1317.

Lin, J.P., Fu, W.Q., Cen, P.L., 2009. Characterization of 5-aminolevulinate synthase from Agrobacterium radiobacter, screening new inhibitors for 5-aminolevulinate dehydratase from Escherichia coli and their potential use for high 5-aminolevulinate production. Bioresource Technol., 100(7):2293-2297. [doi:10.1016/j.biortech.2008. 11.008]

Liu, X.X., Lin, J.P., Qin, G., et al., 2005. Expression of a new hemA gene from Agrobacterium radiobacter in Escherichia coli for 5-aminolevulinate production. Chin. J. Chem. Eng., 13(4):522-528.

Pariser, D., Loss, R., Jarratt, M., et al., 2008. Topical methylaminolevulinate photodynamic therapy using red lightemitting diode light for treatment of multiple actinic keratoses: a randomized, double-blind, placebo-controlled study. J. Am. Acad. Dermatol., 59(4):569-576. [doi:10. 1016/j.jaad.2008.05.031]
Sasaki, K., Watanabe, M., Tanaka, T., et al., 2002. Biosynthesis, biotechnological production and applications of 5-aminolevulinic acid. Appl. Microbiol. Biotechnol., 58(1):23-29. [doi:10.1007/s00253-001-0858-7]

Vanderwerf, M.J., Zeikus, J.G., 1996. 5-Aminolevulinate production by Escherichia coli containing the Rhodobacter sphaeroides hemA gene. Appl. Environ. Microbiol., 62(10):3560-3566.

Viale, A.A., Wider, E.A., Batlle, A.M.D.C., 1987. Porphyrin biosynthesis in Rhodopseudomonas palustris-XI. Extraction and characterization of $\delta$-aminolevulinate synthetase. Comp. Biochem. Physiol. B Comp. Biochem., 87(3):607-613. [doi:10.1016/0305-0491(87)90059-9]

Wang, J.Q., Wu, J.H., Zhang, Z.M., 2006. Expression of 5 -aminolevulinic acid synthase in recombinant Escherichia coli. World J. Microbiol. Biotechnol., 22(5): 461-468. [doi:10.1007/s11274-005-9057-5]

Warnick, G.R., Burnham, B.F., 1971. Regulation of porphyrin biosynthesis. Purification and characterization of $\delta$-aminolevulinic acid synthase. J. Biol. Chem., 246(22):6880-6885.

Xie, L., Hall, D., Eiteman, M.A., et al., 2003a. Optimization of recombinant aminolevulinate synthase production in Escherichia coli using factorial design. Appl. Microbiol. Biotechnol., 63(3):267-273. [doi:10.1007/s00253-0031388-2]

Xie, L., Eiteman, M.A., Altman, E., 2003b. Production of 5-aminolevulinic acid by an Escherichia coli aminolevulinate dehydratase mutant that overproduces Rhodobacter sphaeroides aminolevulinate synthase. Biotechnol. Lett., 25(20):1751-1755. [doi:10.1023/A: 1026035912038]

Zaak, D., Sroka, R., Khoder, W., et al., 2008. Photodynamic diagnosis of prostate cancer using 5-aminolevulinic acid: first clinical experiences. Urology, 72(2):345-348. [doi: 10.1016/j.urology.2007.12.086]

\section{中文㯕要：}

本文题目: 荚膜红细菌（Rhodobacter capsulatus）hemA 基因的高效可溶表达及其酶学性质对比研究 High-level soluble expression of the hemA gene from Rhodobacter capsulatus and comparative study of its enzymatic properties

研究目的：提供一种酶学性质优良的, 可在大肠杆菌体内高活性可溶表达的, 具有工业应用前景的 5-氨基乙酰丙酸合成酶。

创新要点: 利用 E. coli Rosetta (DE3)表达编码荚膜红细菌 5-氨基乙酰丙酸合成酶（RC-ALAS）的 hemA 基因, 实现其在大肠杆菌体内高活性可溶表达。以放射形土壤杆菌和类球红细菌 hemA 基因 表达的 5-氨基乙酰丙酸合成酶 (AR-ALAS 和 RS-ALAS) 为参照, 对分离纯化后的 RC-ALAS 进行酶学性质对比研究。

研究方法: 工程菌的构建如图 1 所示, 酶的分离纯化采用镍柱亲和层析和凝胶过滤层析, 酶学性质的测 定采用对比研究法。

重要结论: (1) RC-ALAS 酶活性高达 $198.2 \mathrm{U} / \mathrm{mg}$, 比 AR-ALAS (151.1 U/mg) 和 RS-ALAS (116.9 U/mg) 分别提高 $31.2 \%$ 和 $69.5 \%$; (2) RC-ALAS 对底物琥珀酰辅酶 A 的专一性常数 $\left(\left(k_{\mathrm{cat}} / K_{\mathrm{m}}\right)^{\mathrm{S}-\mathrm{CoA}}\right)$ 为 1.4989, 高于 AR-ALAS（0.7456）和 RS-ALAS（1.1699），具有较高的催化效率;（3）对含 有荚膜红细菌 hemA 基因的工程菌进行补料分批发酵, 发酵结束时, ALA 的产量高达 $8.8 \mathrm{~g} / \mathrm{L}(67 \mathrm{mmol} / \mathrm{L})$ 。

关键词组：5-氨基乙酰丙酸; 荚膜红细菌（Rhodobacter capsulatus）; 高效表达; 酶学性质 